\title{
Physico-mechanical properties changes in virgin and recycled polyethylene fibers during recycling process
}

The aim of this work is to study the changes of physico-mechanical properties of polyethylene during recycling stages. All raw materials were taken virgin and recycled polyethylene granules used for producing plastic bags. Initially they were identified with the vibration spectroscopy FT-IR and Raman, which marked the presence of additives in recycled samples. As recycling process was used as a micro-pilot system; comprising the melt flow index device and a universal mill grinding. Among mechanical properties that were identified were density, specific gravity, melt flow index, yield strength and elasticity modulus and tensile strength. From the results analysis were observed changes in physical and mechanical properties for polyethylene samples by recycling cycles.

Keywords: physic-mechanical properties, virgin and recycled polyethylene, vibration spectroscopy.

\section{INTRODUCTION}

During the last decades, the growth of welfare has led to the growth of the materials used to meet everyday needs. The use of plastic materials has been increased drastically, most commonly plastic bags and bottles. Despite the improvements made in the production of plastic materials, their volume has increased significantly and causes many environmental problems, which are associated with their very slow time of degradation. In recent years the EU policies have focused mainly on three areas: reduction, reuse and recycling. Recycling is a challenge to society and the chemical industry. Given the fact that most of the plastic materials belong to the thermoplastic category, they can be mechanically recycled. For other plastic materials the application of chemical recycling is not widely used because of its high cost [1,2].

During the recycling process, plastic materials lose many of their properties, both as a consequence of oxidative processes, and due to the incorporation of foreign materials in their structure, which is a result of their inefficient separation. Functional additives in the polymeric structure are generally used to recover their properties during the recycling process. These additives, however, affect of physicochemical and engineering properties of the plastic materials, as well as in their appearance $[3,4]$.

\section{MATERIALS AND METHODS}

The plastic materials used in this study are one sample of virgin polyethylene and two samples of

Author's address: ${ }^{1}$ Department of industrial chemistry, Faculty of natural sciences, University of Tirana, Albania, ${ }^{2}$ School of mining and metalurginal engineering, National technical university of Athens, Greece

Received for Publication: 12. 06. 2014.

Accepted for Publication: 18. 08. 2014. recycled polyethylene (blue and white, semitransparent). Both samples are in the form of granules, a form that is used in the Albanian market for the production of plastic bags.

For each of the three samples 6 recycling stages were applied. For each stage the physicomechanical properties were determined. For recycling the micro-pilot method was used, which is based on a modified melt flow index apparatus (MFI) and a Fritsch Cutting Mill Pulverisette 15. The temperature used for the MFI instrument is $200{ }^{\circ} \mathrm{C}$, the force exerted is $2.16 \mathrm{~kg}$ and the amount of polyethylene used was $4 \mathrm{gr}$. Polyethylene fibers were obtained with diameters ranging between $1.5-2 \mathrm{~mm}$.

Initial spectroscopic characterization was performed with FTIR and Raman, both prior and after recycling, and the observed changes are shown in the corresponding spectra (Figs. 1-3). Most changes are due to the presence of additives in the recycled materials. FTIR and Raman spectra were taken from polymer pellets weighted $20-30 \mathrm{mgr}$ and with diameter of $13 \mathrm{~mm}$. They were formed in $180^{\circ} \mathrm{C}$ temperature (more than $20^{\circ}$ below polymer glass transition temperature) and pressed in pellet form under 1 ton pressure with the help of a Perkin Elmer hydraulic press [5]. Crystallization of the pellets was carried out at room temperature.

The FTIR and Raman instruments used in the study are respectively a Perkin Elmer GX1, equipped with the 'Spectrum' software, and a Renishaw RamaScope RM1000 Raman microspectrometer with a laser with radiation wavelength of 633 $\mathrm{nm}$ (red) equipped with a Leica DMLM optical microscope. The resolution of the FTIR instrument was $4 \mathrm{~cm}^{-1}$ and the recorded wavenumber range was from $400-4000 \mathrm{~cm}^{-1}$ (MID IR region). Each analysis is the result of the integration of ten individual spectra scans, in order to reduce noise. The wavenumber range for Raman spectra was from $450-3500 \mathrm{~cm}^{-1}$. 
The measured physico-mechanical properties include density, specific gravity, melt flow index, yield strength and elasticity modulus, and tensile strength. Density was determined according to the ASTM D 792 standard and the melt flow index according to the ASTM D1183 standard with a $6 \mathrm{MPa}$ RayRan instrument. Both of these properties affect the recycling process of plastic materials[6]. The mechanical properties were determined by the 'uniaxial tensile test'. The tensile test was carried out with the instrument Model YG026B, with an axial attraction in one direction. The forceelongation diagrams obtained were converted in strain-stress diagrams in order to determine their

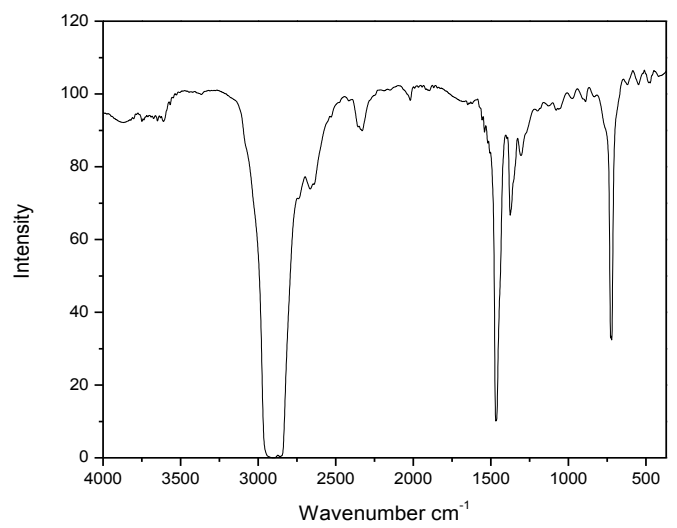

mechanical properties in tensile strength, yield strength and elasticity modulus-taking into account the cross sectional area of fibers and their initial length.

\section{RESULTS AND DISCUSSION}

The samples of polyethylene were analyzed first in order to determine the additives in their structure. In Figs. 2-4 the FTIR and Raman spectra are shown, for all three samples of polyethylene. Raman spectra of colored and recycled polyethylene exhibit high fluorescence and therefore they are background-corrected.

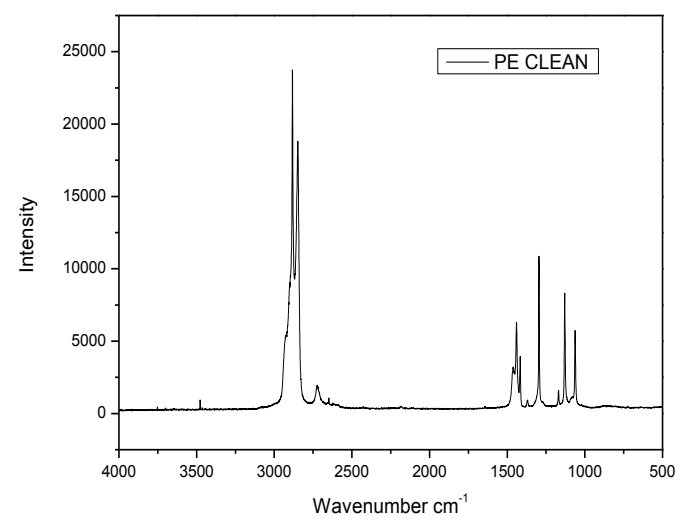

Figure 1 - FT-IR and Raman spectrum for virgin polyethylene
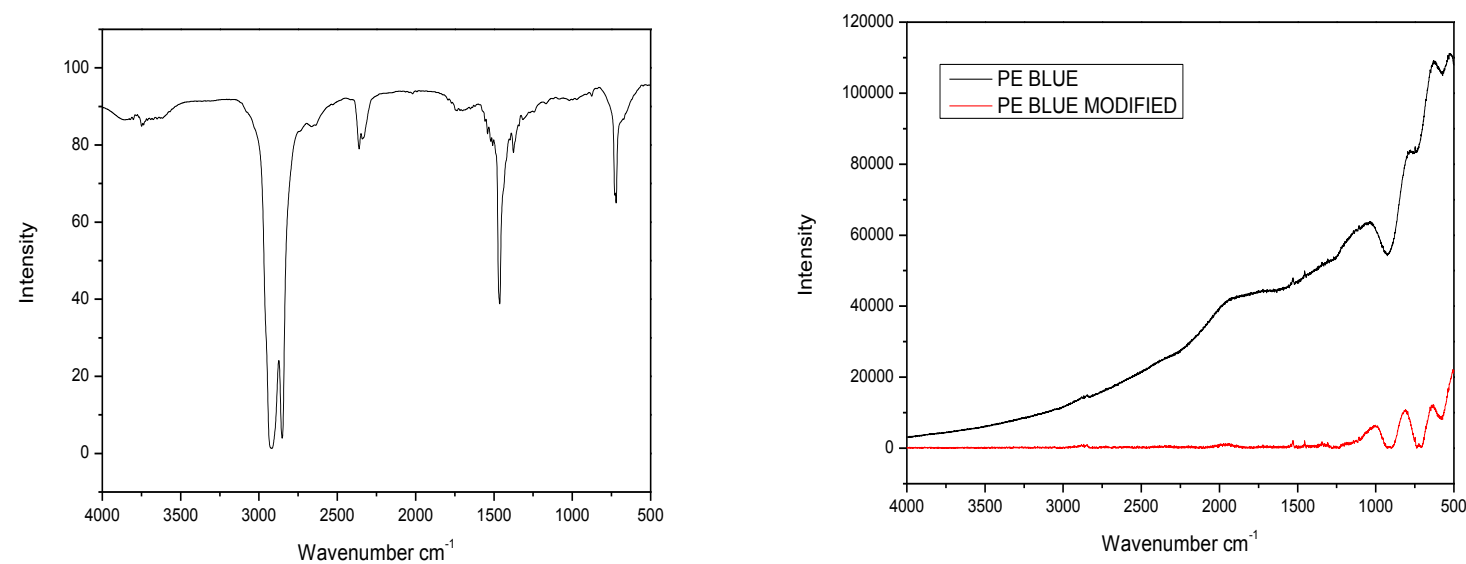

Figure 2 - FT-IR and Raman spectrum for blue recycled polyethylene
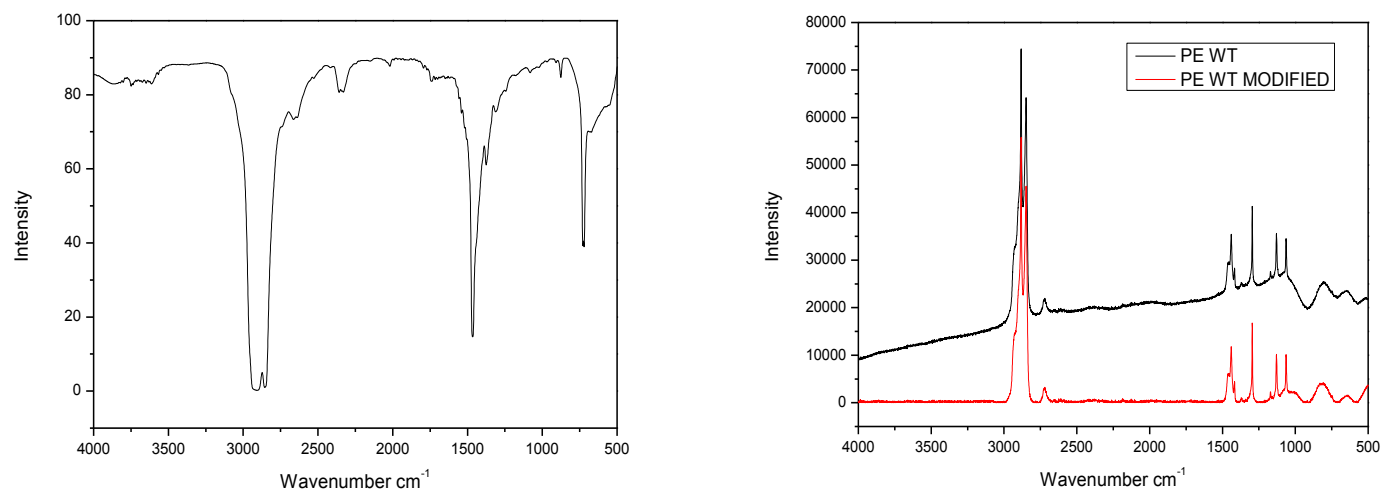

Figure 3 - FT-IR and Raman spectrum for white semi-transparent recycled polyethylene 
FTIR spectra correctly identified polyethylene for all three samples, i.e., virgin polyethylene, as well as recycled polyethylene. Three groups of peaks, i.e., the wavenumbers $2916.5-2855.3 \mathrm{~cm}^{-1}$, $1492.2-1466.1 \mathrm{~cm}^{-1}$, and $749.5-723.33 \mathrm{~cm}^{-1}$ are identified, that result from the absorptions of bonds $\mathrm{C}-\mathrm{H}$ and $\mathrm{C}-\mathrm{C}$ of polyethylene in the infrared region [7] Identification of additives in recycled polyethylene by FTIR spectra cannot be performed accurately due to the low intensity of the measured peaks and their overlap and, additionally, due to the small amount of additives used. Raman spectra from virgin polyethylene show, in addition to peaks from the vibrations of polar molecules, the vibration
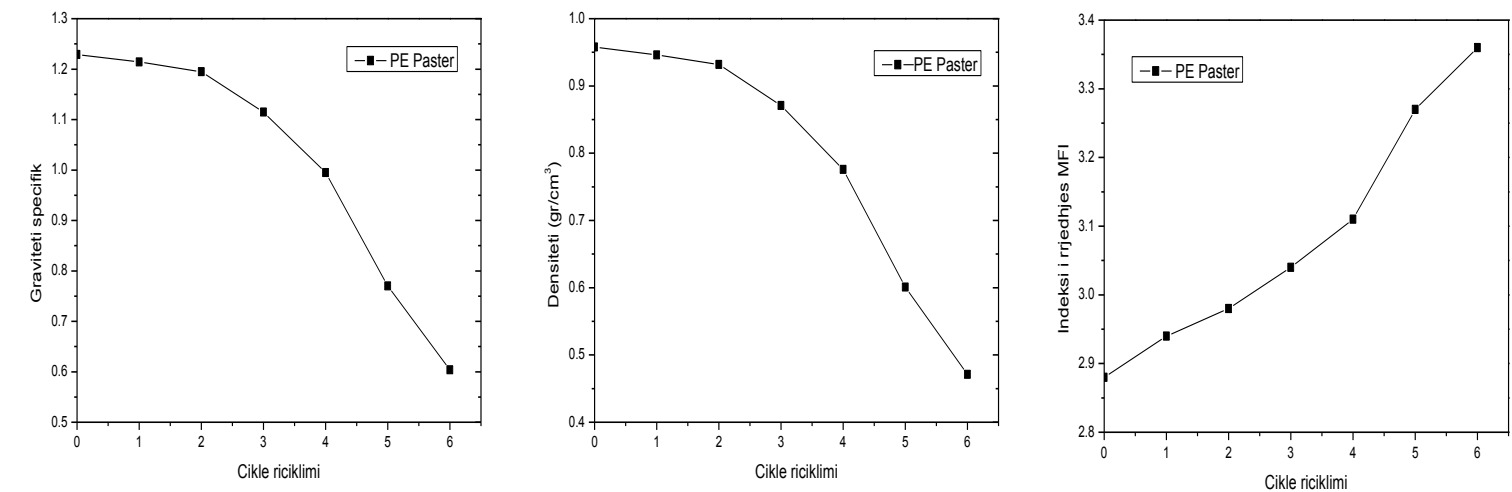

Figure 4 - The changes in specific gravity, density and melt flow index for virgin polyethylene, due to the recycled cycles.
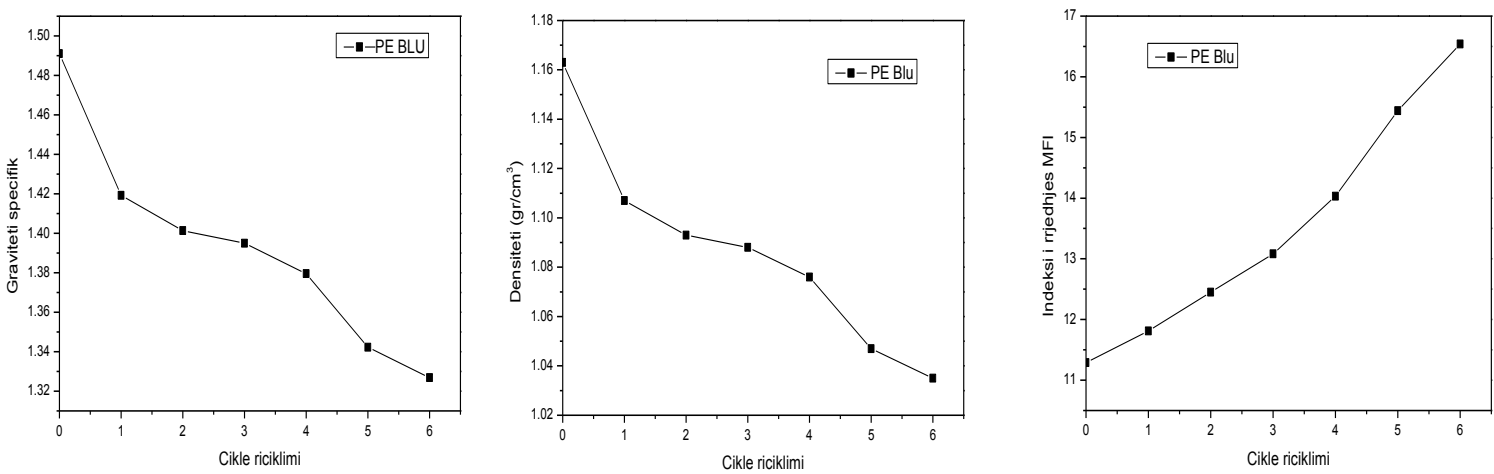

Figure 5 - The changes in specific gravity, density and melt flow index for blue recycled polyethylene, due to the recycled cycles.
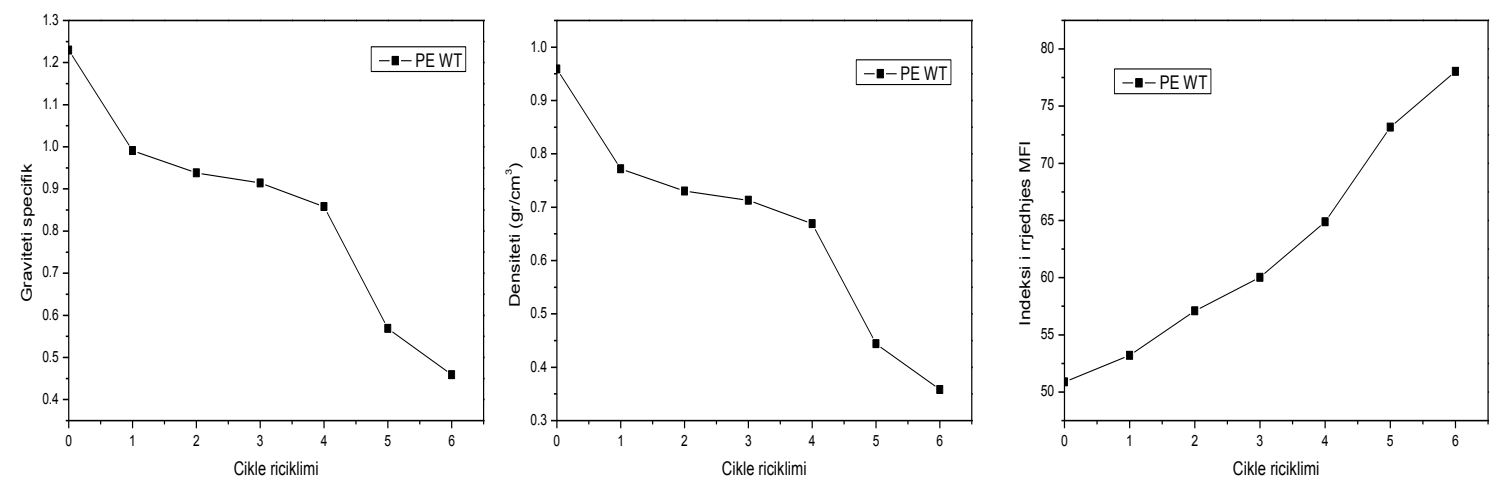

Figure 6 - The changes in specific gravity, density and melt flow index for white semi-transparent recycled polyethylene, due to the recycled cycles. 
The results for all three samples show a decrease of the specific gravity and the density of the material after each recycling stage, which is a result of the degradation of polyethylene. The increase of the flow index value is also a sign of degradation, since during the recycling process the molecular weight of polyethylene decrease, making it more susceptible to flow. The decrease of the values of specific gravity and density is more evident for two samples of recycled directly after the first stage. A fourth recycling stage generally results to a total degradation of the polymers.
From the load-elongation diagrams, the strainstress diagrams were also constructed, taking into account the cross section area of the samples as well as their initial lengths. From them, the mechanical properties were identified with the same procedure described in Callister[8]. To measure the mechanical properties we fabricated fibers, and at least three measurements were carried out in each fiber. The calculated results are shown on Tables $1-3$.

Table 1 - Mechanical properties after each recycling stage for virgin polyethylene

\begin{tabular}{|l|c|c|c|c|c|c|}
\hline & 0 & 1 & 2 & 3 & 4 & 5 \\
\hline Elasticity modulus [MPa] & $378 \pm 17$ & $390 \pm 25$ & $365 \pm 15$ & $380 \pm 20$ & $370 \pm 25$ & $383 \pm 15$ \\
\hline Yield point [MPa] & $15,6 \pm 2.1$ & $15 \pm 2.3$ & $14.55 \pm 2$ & $15.1 \pm 1.5$ & $14.7 \pm 2.4$ & $15.3 \pm 2.2$ \\
\hline Tensile strength [MPa] & $22.6 \pm 4$ & $21.33 \pm 3$ & $24.25 \pm 4$ & $25.1 \pm 5$ & $24.5 \pm 3$ & $25.5 \pm 4$ \\
\hline
\end{tabular}

Table 2 - Mechanical properties after each recycling stage for blue recycled polyethylene

\begin{tabular}{|l|c|c|c|c|c|c|}
\hline & 0 & 1 & 2 & 3 & 4 & 5 \\
\hline Elasticity modulus [MPa] & $247 \pm 18$ & $252 \pm 24$ & $240 \pm 12$ & $258 \pm 16$ & $260 \pm 14$ & $263 \pm 21$ \\
\hline Yield point [MPa] & $9.87 \pm 2.1$ & $10.1 \pm 2.2$ & $9.6 \pm 1.9$ & $10.3 \pm 1.7$ & $10.4 \pm 1.8$ & $10.5 \pm 2.3$ \\
\hline Tensile strength [MPa] & $14,1 \pm 2.7$ & $14.5 \pm 3.1$ & $14.2 \pm 2.4$ & $14.7 \pm 2.1$ & $14.8 \pm 2.2$ & $15.1 \pm 2.0$ \\
\hline
\end{tabular}

Table 3 - Mechanical properties after each recycling stage for white semi-transparent polyethylene

\begin{tabular}{|l|c|c|c|c|c|c|}
\hline & 0 & 1 & 2 & 3 & 4 & 5 \\
\hline Elasticity modulus [MPa] & $218 \pm 15$ & $180 \pm 23$ & $211 \pm 12$ & $227 \pm 26$ & $210 \pm 17$ & $207 \pm 10$ \\
\hline Yield point [MPa] & $6.53 \pm 2.1$ & $5.4 \pm 2.6$ & $6.32 \pm 2.1$ & $6.82 \pm 1.9$ & $6.3 \pm 2.2$ & $6.2 \pm 1.8$ \\
\hline Tensile strength [MPa] & $13.06 \pm 3.2$ & $10.7 \pm 2.1$ & $12.6 \pm 1.8$ & $9.72 \pm 1.6$ & $8.96 \pm 1.8$ & $8.9 \pm 1.7$ \\
\hline
\end{tabular}

From our results, a fluctuation of the values of the mechanical properties is observed. Due to degradation, we would accept a decrease in mechanical properties values, due to reduction of molecular mass. It is possible that in addition to the phenomenon of degradation during mechanical recycling, the mechanical properties of the samples also affect their molecular orientation. In this way, the polymeric chains are oriented in the direction along the length of the polymeric fibers, thus increasing their mechanical properties in this direction. In conclusion, the impact of recycling on the mechanical properties of polyethylene remains to be studied in higher precision with a two axes tensile test.

\section{CONCLUSIONS}

The spectroscopic characterization method of infrared vibration (FTIR) enables the accurate identification of polyethylene, even when it contains many additives or it is recycled. The definition of the additives themselves turns out to be difficult due to the low height compared to background of the peaks. For the identification of the additives complementary methods are also required, such as chromatography or NMR. Raman spectra enable accurate identification only in the case of pure polyethylene, because the background increases significantly when recycled polyethylene samples are measured. This is due to the presence of additives in the structure of polyethylene, but also depends on the number of recycling stages.

The physical properties of polyethylene decrease with increasing number of recycling stages, which is a result of their degradation and the reduction of their polymeric chain. Thus, degradation is more evident in the case of recycled polyethylene, because of their prior processing.

The variation of the measured mechanical properties shows that the negative impact of degradation already affects the axial orientation of the molecular polyethylene fibers. It also affects the uniformity of the mechanical properties of the polymeric fibers, but in this case it is necessary that additional measurements have to be made, e.g., a two-axes tensile test. 


\section{LITERATURE}

[1] European Commission 2013: GREEN PAPER - On a European Strategy on Plastic Waste in the Environment, http//ec.europa.eu/envinronment/waste

[2] APM 2010: Plastics - the Facts 2010, An analysis of European plastics production, demand and recovery for 2009, Association of Plastics Manufactures: $\mathrm{http} / /$ plasticseurope.com

[3] Francesco Paolo La Mantia (1998) Recycled plastics: additives and their effects on properties; Chapman \&Hall,

[4] J. C. J. Bart (2005), Additives In Polymers: Industrial Analysis And Applications, John Wiley \& Sons
[5] D.S.Achilias, C.Roupakias, P.Megalokonomos, A.A. Lappas, E.V.Antonakou (2007) Chemical recycling of plastic waste made from polyethylene (LDPE and HDPE) and polypropylene(PP), ELSEVIER 03043894

[6] Shan-Fu Shen (1990), Simulation of the processing of thermoset polymers, International Journal for Numerical Methods in Engineering, Volume 30. Issue 8, pages 1633-1647

[7] D.W. Mayo, F.A. Miller, and R.W. Hannah (2004) Course Notes on the Interpretation of Infrared and Raman Spectra, Wiley-Interscience, Hoboken.

[8] Willam. D.Callister.Jr, 2007 Materials science and engineering-An introduction, seventh edition, Willey

\section{IZVOD}

\section{PROMENE FIZIČKO-MEHANIČKIH SVOJSTAVA SVEŽIH I RECIKLIRANIH POLIETILENSKIH VLAKANA}

Cilj ovog rada je bio da se prouče promene fizičko-mehaničkih svojstava polietilena tokom faza reciklaže. Za ispitivanja su uzete čiste i reciklirane polietilenske granule, koje se koriste za proizvodnju plastičnih kesa. U početku su uzorci bili ispitani pomoću spektroskopije FTIR i Raman, čime je ustanovljeno prisustvo aditiva u recikliranim uzorcima. Proces reciklaže je korišćen kao mikro-pilot sistem; sadrži uređaj za protok i univerzalni mlin. Među mehaničkim osobinama, koje su identifikovane, su gustina, specifična težina, topivi indeks protoka, tečenje i modul elastičnosti $i$ zatezna čvrstoća. Iz analize rezultata su primećene promene fizičkih i mehaničkih svojstava za reciklirane uzorke polietilenska.

Ključne reči: fizičko-mehanička svojstva, sveži i reciklirani polietilen, spektroskopija

Originalni naučni rad

Primljeno za publikovanje: 12. 06. 2014.

Prihvaćeno za publikovanje: 18. 08. 2014. 